\title{
Determination of the Chemical Composition, Amino Acid Levels and Energy Values of Different Poultry Offal Meals for Broilers
}

\section{-Author(s)}

Silva EP da ${ }^{* *}$

Rabello CBV ${ }^{1}$

Lima MB de ${ }^{1}$

Arruda EMF de

Ludke JV2

Ludke MCMM

'Universidade Federal Rural de Pernambuco, Brazil, Dois Irmãos, CEP: 51.191-900, Recife, Pernambuco, Brazil.

2EMBRAPA Suínos e Aves.

\section{Mail Adress}

* Corresponding author:

E-mail: edneysilva@oi.com.br

\section{"Keywords}

Alternative feedstuffs, poultry by-products, passage rate.

\begin{abstract}
The aim of this study was to determine the chemical composition, amino acid content and energy values, as well as to quantify the passage rate in the digestive tract of three different poultry offal meals (POM), in two experiments carried out with broilers. In the first experiment, metabolizable energy values were determined (AMEn and TMEn) using the method of total excreta collection. In this experiment, 15015 -d-old male and female broilers were distributed according to a completely randomized experimental design with 5 treatments of 5 replicates of 6 birds each. The following treatments were applied: a reference diet, three test diets consisting of $250 \mathrm{~g} / \mathrm{kg}$ of the tested ingredient (POM) $+750 \mathrm{~g} / \mathrm{kg}$ of the reference diet, and one group of birds fasted for excreta collection to determine endogenous and metabolic losses. In the second experiment, POM passage rate results were obtained using 90 26-d-old broilers distributed according a completely randomized design with three treatments of 5 replicates of 6 birds each. POM passage rate was correlated ( $r=-99.86 \%)$ with its EE content. The evaluated POMs presented the following ME values: 16,727; 15,781 and 17,443 MJ AMEn $/ \mathrm{kg}$ and 17,877; 15,882 and 17,527 MJ TMEn / kg for samples A, $B$ and $C$, respectively.
\end{abstract}

\section{INTRODUCTION}

Feed formulas based on traditional feedstuffs are becoming increasingly expensive because the prices of the commonly used conventional sources of protein (soybean meal) and the phosphorus (dicalcium phosphate) are becoming incompatible with chicken prices. For this reason, the use of animal ingredients may be an alternative for the nutritionists to formulate more economical feeds, despite of restrictions of the foreign markets.

In the specific case of poultry offal meals, the different ratios of the parts included in the meal, such as head, feet, back, and other rejected parts derived from slaughter and deboning may result in significant variations in their composition, and consequently, in the utilization in their energy content.

The success of the formulation depends on the adequate supply of animal nutritional requirements, which requires constant updating of the nutritional matrix with the composition of the feedstuffs that will be included in feed formulation. However, it is not always possible to obtain this information, making nutritionist resort to the composition of feedstuffs published in recommendation tables, which not always accurately reflect the chemical and energy composition of each ingredient.

This situation is shown in the study of Nascimento et al. (2002). The authors evaluated five different poultry offal meals and determined a difference of 3,939 MJ/kg metabolizable energy between the evaluated meals, with ranges between 11,859 and $15,798 \mathrm{MJ} / \mathrm{kg}$. 
Differences in the proportion of carcass parts included and in the manufacturing process result in different compositions, particularly relative to their metabolizable energy values. So, when using feedstuff composition tables for feed formulation, dietary energy values may be under- or overestimated, affecting feed calorie content, as well as the efficiency and the cost of energy intake per weight gain.

The objective of the present study was to evaluate the chemical composition and amino acid values, to estimate gut passage rate, and the energy values of different poultry offal meal in an experiment carried out with broilers.

\section{MATERIALS AND METHODS}

The experiment was carried out at the Department of Animal Science of Universidade Federal Rural de Pernambuco, Brazil. Three different poultry offal meals were obtained from three different processing plants in the state of Pernambuco, Brazil. Samples from each meal were collected and submitted to the Animal Nutrition Laboratory (LAN) of the Department of Animal Science of that university, and analyzed for moisture, dry matter, crude protein, ether extract, gross energy, ashes, calcium, phosphorus, sodium, chlorine, and potassium contents, as well as for density and geometric mean diameter. Samples of about 100 $\mathrm{g}$ of each meal were collected, duly identified, and analyzed for their essential amino acid contents.

The chemical analyses were carried out at the Animal Nutrition Laboratory (LAN) of the Department of Animal Science of the Universidade Federal Rural de Pernambuco, except for gross energy, calcium, phosphorus, sodium, chlorine and potassium analyses. Minerals were prepared at LAN and sample reading and standard curve determination were performed by flame photometry and atomic absorption at the Soil Fertility and Chemistry laboratory of that university.

Feedstuff, feed, and excreta gross energy was determined in a calorimetric bomb (IKA WERKE, model 2000) at the Animal Nutrition Laboratory of the Department of Animal Science Nutrition of Universidade Federal Rural do Semiárido. Feedstuff amino acid contentes were determined by nearinfrared reflectance (NIR) by the company Degussa.

Chemical analyses were carried out using the methodologies described by Silva \& Queiroz (2002). The geometric mean diameter (GMD) of each meal was determined according the procedure described by Zanotto \& Bellaver (1996), using a vibrator assembly consisting of the device VIATEST 76773 KUHARDT and seven sieves $(4,2,1.20,0.60,0.30,0.15$, and $0 \mathrm{~mm})$.
A metabolic trial was carried out, using the method of total excreta collection, to determine the apparent and true coefficients of dry matter metabolizability (DMMC - A and DMMC - T, respectively), apparent and true coefficients of gross energy metabolizability (GEMC - A and GEMC - T, respectively), and apparent metabolizable energy (AME), apparent metabolizable energy corrected for nitrogen balance (AMEn), true metabolizable energy (TME) and true metabolizable energy corrected for nitrogen balance (TMEn) values of the three poultry offal meal for broilers.

A flock of 540 straight-run broiler chicks were reared on floor pens, and were offered a diet based on corn and soybean meal formulated to supply their nutritional requirements. Birds were then selected by weight in order to obtain maximal uniformity during the experimental period. A number of 150 straight run Cobb broilers, with initial age of 15 days, were used in the metabolism assay carried out at the Non-Ruminant Digestibility Laboratory. These birds were housed in battery cages measuring $1.00 \times 0.50 \times 0.50 \mathrm{~m}$ in an environmentally-controlled room. A lighting program of 24 hours of light (natural + artificial) was adopted. During the experimental period, feed intake and excretion data were recorded. Environmental temperature was maintained at $24^{\circ} \mathrm{C} \pm 1.5^{\circ} \mathrm{C}$.

Birds were distributed according to a a completely randomized experimental design with five treatments of five replicates of six birds each, being three males and three females. The following treatments were applied: a reference diet (T1) based on corn and soybean meal (Table 1) and three test diets (T2, T3, T4) consisting of $250 \mathrm{~g} / \mathrm{kg}$ of the tested ingredient $+750 \mathrm{~g} / \mathrm{kg}$ of the reference diet (T1). The fifth treatment (T5) consisted of a group of birds fasted to quantify fecal metabolic dry matter + endogenous urinary dry matter, fecal metabolic nitrogen + endogenous urinary nitrogen, and fecal metabolic energy + endogenous urinary energy in order to estimate true metabolizability of dry matter and of energy of the tested feedstuffs.

The diets offered during the rearing phase and during the experimental period were formulated based on feedstuff composition and on the specific nutritional requirements of broilers for each rearing phase, as recommended by Rostagno et al. (2005).

Under the floor of the metabolic cages (experimental units), trays covered with canvas were place for total excreta collection to determine metabolic and endogenous losses. The first five days were used for bird adaptation to the cages and to the experimental diets, and the next five days for total excreta collection. Endogenous and metabolic losses were determined 
Table 1 - Ingredient and nutritional composition of the reference diet.

\begin{tabular}{lc}
\hline Ingredients & $\mathrm{g} / \mathrm{kg}$ \\
\hline Corn grain & 610.89 \\
soybean meal 45\% & 324.61 \\
Soybean oil & 27.02 \\
Dicalcium phosphate & 17.17 \\
Calcitic limestone & 8.70 \\
\hline Ingredients & $\mathrm{g} / \mathrm{kg}$ \\
\hline Salt & 4.79 \\
L-Lysine HCl, 788g/kg & 1.77 \\
DL-Methionine, 990g/kg & 2.15 \\
Vitamin supplement ${ }^{1}$ & 1.00 \\
Trace mineral supplement ${ }^{2}$ & 0.50 \\
Choline chloride $600 \mathrm{~g} / \mathrm{kg}$ & 0.50 \\
Sodium salinomycin 120g/kg & 0.50 \\
Zinc bacitracin 150g/kg & 0.40 \\
Total & 1000.00 \\
\hline Calculated composition & \\
\hline
\end{tabular}

Corrected apparent metabolizable energy, $\mathrm{MJ} / \mathrm{kg}$

Crude protein, $\mathrm{g} / \mathrm{kg}$

200.4

Calcium, $\mathrm{g} / \mathrm{kg}$

Available phosphorus, $\mathrm{g} / \mathrm{kg}$

Digestible Methionine+Cystine, $\mathrm{g} / \mathrm{kg}$

Digestible Lysine, $\mathrm{g} / \mathrm{kg}$

10.94

Digestible Threonine, $\mathrm{g} / \mathrm{kg}$

Digestible Tryptophan, g/kg

Added choline $(\mathrm{mg} / \mathrm{kg}$ )

Linoleic acid, $\mathrm{g} / \mathrm{kg}$

Sodium (\%)

1 Guaranteed levels per kg product: Vit.A, 6,000,000IU; Vit.D3, 1,000,000IU; Vit.E, 10,000 mg; Vit. B12, 6,000 mcg; Vit. K3, 1,000; Niacin, 10,000 mg; Pyridoxine, 800 mg; Riboflavin, 2,000 mg; Thiamin, 600 mg; Biotin, 30 mg; Calcium Pantothenate, 8,000 mg; Selenium, $400 \mathrm{mg}$.

${ }^{2}$ Guaranteed levels per kg product: Copper, 18,000 mg; Zinc, 120,000 mg; lodine, 2,000mg; Iron, 60,000 mg; Manganese, 120,000 mg.

after a period of 24 hours of fasting for cleaning of total digestive tract, and then 48 hours for the collection of the total material excreted. The calculation of DMMC - V, GEMC - V, TME, and TMEn considered the endogenous and metabolic losses corrected for five experimental days. During the experiment, excreta and endogenous and metabolic losses were collected twice daily with an interval of 12 hours between collections. The collected material was placed in duly identified bags, weighed in a 1-g precision scale, subtracting bag weight, and subsequently frozen at $-20^{\circ} \mathrm{C}$.

The mash diets were offered ad libitum during the entire experimental period. Ferric oxide in powder was added at a level of $10 \mathrm{~g} / \mathrm{kg}$ to the experimental diets as fecal marker in the beginning and end of the period of total excreta collection. At the end of the experiment, excreta and endogenous and metabolic losses were thawed and homogenized per experimental unit. An aliquot of $500 \mathrm{~g}$ of excreta was sampled, whereas for endogenous and metabolic losses, all the collected material was used.

Samples were pre-dried in a forced-ventilation oven at $55^{\circ} \mathrm{C}$ for 72 hours. Samples were then ground in grinder with 1-mm sieve and analyzed for dry matter, nitrogen, and gross energy contents, according to the previously described methods.

The coefficients of DMMC - A, DMMC - V, GEMC A, GEMC - V and AME, AMEn, TME and TMEn values of the three tested poultry offal meals were calculated using the formulas proposed by Matterson et al. (1965). Considering the gross energy (GE) and AMEn values of the feedstuffs, the coefficient of gross energy metabolizability (GEMC) was calculated according the equation of the ARC (1980).

In order to determine feed passage rate, 90 Cobb broilers ( 45 males and 45 females), with an initial age of 26 days, were distributed according to a completely randomized experimental design into three treatments of five replicates of six birds per experimental unit, with three males and three females each. Treatments were based on the feeding of the pure tested feedstuffs, i.e., the poultry offal meals obtained from the three different processing plants: Processing Plant A (T1), Processing Plant B (T2) and Processing Plant C (T3).

Birds were fed ad libitum only the tested poultry offal meal for a limited time. In order to facilitate excreta separation and collection, $1 \%$ of a blue dye was added to the total amount of feed in the feeder. At the end of 12 hours, precisely, of ad libitum feeding, residues were removed, and the same feedstuff was offered, but with the addition of a red dye (ferric oxide) used as marker. The first collection was made six hours after the first marked excreta appeared, and the second collection after 12 hours of intake, as determined by the excretion 
of red-marked excreta. Average temperature during the experiment was $25^{\circ} \mathrm{C}$.

The total amount of excreta was weighed and placed in plastic bags identified per experimental unit and frozen at $-22{ }^{\circ} \mathrm{C}$. Excreta samples were prepared as described above. Only dry matter content was determined. Passage rate was interpreted using the information on dry matter excreted per hour (DM/h), was calculated according to the following equation:

$\mathrm{DM} / \mathrm{h}=\frac{\text { Total excretion } \mathrm{g} \times(\% \mathrm{ADS} / 100) \times(\% \mathrm{ODS} / 100)}{12 \mathrm{~h}}$

where; \% ADS = air-dried sample at $55^{\circ} \mathrm{C}$ for $72 \mathrm{~h}$, and $\%$ ODS = oven-dried sample at $105^{\circ} \mathrm{C}$ for $16 \mathrm{~h}$.

The coefficients of metabolizability and feedstuff passage rate were submitted to analysis of variance, and when differences were detected by the $\mathrm{F}$ test, the test of Student-Newman-Keuls was applied, at 5\% probability level. Feedstuff passage rates were tested by Pearson's parametric correlations at $5 \%$ significance level. Statistical analyses were carried out by the statistical package SAEG - UFV, version 9.1 (2006).

\section{RESULTS}

Table 2 shows the chemical composition results of the three tested poultry offal meals. Crude protein, ether extract, gross energy and mineral (calcium, phosphorus, sodium, chlorine and potassium) contents widely varied among meals. It was determined that sodium, chlorine and potassium content were negatively correlated with ash content (Table 3 ).

Density varied between 425 and $533 \mathrm{~g} / \mathrm{L}$ according to ether extract content. These two parameters presented a highly significant correlation of 0.999 $(p<0.001)$.

More than $90 \%$ of the particles of meals $A$ and B were classified as medium (54\%) and fine (42\%), whereas medium particles $(67 \%)$ predominated in meal $C$, where the remaining 35\% consisted of fine $(19 \%)$ and coarse $(17 \%)$ particles.

Table 2 - Physical-chemical composition and energy content of the tested poultry offal meals ${ }^{1}$.

\begin{tabular}{|c|c|c|c|c|c|}
\hline \multirow{2}{*}{ Parameters } & \multicolumn{5}{|c|}{ Poultry offal meals } \\
\hline & Unit & A & B & $\mathrm{C}$ & Mean \pm SD \\
\hline Dry matter & $\mathrm{g} / \mathrm{kg}$ & 933.4 & 925.9 & 910.6 & $933.4 \pm 6.7$ \\
\hline Crude protein & $\mathrm{g} / \mathrm{kg}$ & 627.3 & 643.0 & 545.5 & $627.3 \pm 38.0$ \\
\hline Ether extract & $\mathrm{g} / \mathrm{kg}$ & 154.2 & 114.7 & 227.7 & $154.2 \pm 33.1$ \\
\hline Gross energy & $\mathrm{kcal} / \mathrm{kg}$ & 21.771 & 20.817 & 23.165 & $21.767 \pm 0.8$ \\
\hline Ashes & $\mathrm{g} / \mathrm{kg}$ & 101.8 & 94.5 & 111.5 & $101.8 \pm 4.9$ \\
\hline Calcium & $\mathrm{g} / \mathrm{kg}$ & 26.1 & 27.9 & 31.1 & $26.1 \pm 1.4$ \\
\hline Phosphorus & $\mathrm{g} / \mathrm{kg}$ & 13.7 & 15.2 & 16.9 & $13.7 \pm 0.9$ \\
\hline Sodium & $\mathrm{g} / \mathrm{kg}$ & 4.7 & 5.5 & 3.6 & $4.7 \pm 0.5$ \\
\hline Chlorine & $\mathrm{g} / \mathrm{kg}$ & 5.9 & 6.9 & 4.6 & $5.9 \pm 0.6$ \\
\hline Potassium & $\mathrm{g} / \mathrm{kg}$ & 7.8 & 9.6 & 5.0 & $7.8 \pm 1.3$ \\
\hline Density & $\mathrm{g} / \mathrm{L}$ & 457.64 & 425.13 & 533.67 & $457.64 \pm 11.79$ \\
\hline Energy density² & $\mathrm{kj} / \mathrm{cm}^{3}$ & 7.66 & 7.24 & 9.29 & $7.66 \pm 0.59$ \\
\hline $\mathrm{GMD}^{3}$ & $\mu \mathrm{m}$ & 639.09 & 656.21 & 722.90 & $639.09 \pm 44.28$ \\
\hline \multicolumn{6}{|c|}{$\begin{array}{l}\text { SD, standard error } \\
1 \text { Values expressed on as-is basis } \\
2 \text { Estimated on the AMEn values presented in Table } 6 \\
{ }^{3} \text { Geometric mean diameter }\end{array}$} \\
\hline
\end{tabular}


Table 3 - Correlation coefficients between ashes and main minerals.

\begin{tabular}{lccc}
\hline Parameters $^{1}$ & & $\begin{array}{c}\text { Simple correlation } \\
\text { coefficient }(\boldsymbol{r})\end{array}$ & Significance \\
\hline \hline \multirow{4}{*}{ Ashes } & $\mathrm{Ca}$ & 0.6927 & 0.2564 \\
& $\mathrm{P}$ & 0.5980 & 0.2960 \\
& $\mathrm{Na}$ & -0.9999 & 0.0001 \\
& $\mathrm{Cl}$ & -0.9999 & 0.0001 \\
& $\mathrm{~K}$ & -0.9999 & 0.0001 \\
\hline
\end{tabular}

Table 4 presents amino acid contents and the correlation coefficients with crude protein of the three poultry offal meals. The analyzed amino acids presented high correlation with crude protein content, except for cystine, which correlation value was low and not significant.

\section{Metabolism assay}

The gastrointestinal passage rates of the tested poultry offal meals and their correlation with fat content of the respective meals are shown Table 5. The

Table 4 - Amino acid composition of the tested poultry offal meals'.

\begin{tabular}{|c|c|c|c|c|}
\hline \multirow{2}{*}{ Essential amino acids } & & \multicolumn{3}{|c|}{ Poultry offal meals } \\
\hline & Unit & A & B & $C$ \\
\hline & & Total & Total & Total \\
\hline Methionine & $\mathrm{g} / \mathrm{kg}$ & 11.6 & 13.0 & 10.1 \\
\hline Cystine & $\mathrm{g} / \mathrm{kg}$ & 9.2 & 7.7 & 7.3 \\
\hline Methionine+Cystine & $\mathrm{g} / \mathrm{kg}$ & 20.5 & 20.1 & 17.0 \\
\hline Lysine & $\mathrm{g} / \mathrm{kg}$ & 34.1 & 36.9 & 28.1 \\
\hline Threonine & $\mathrm{g} / \mathrm{kg}$ & 24.5 & 25.3 & 20.1 \\
\hline Tryptophan & $\mathrm{g} / \mathrm{kg}$ & 6.2 & 7.0 & 4.7 \\
\hline Arginine & $\mathrm{g} / \mathrm{kg}$ & 39.6 & 40.6 & 36.4 \\
\hline Isoleucine & $\mathrm{g} / \mathrm{kg}$ & 23.5 & 24.1 & 19.6 \\
\hline Leucine & $\mathrm{g} / \mathrm{kg}$ & 43.5 & 44.4 & 35.9 \\
\hline Valine & $\mathrm{g} / \mathrm{kg}$ & 29.2 & 28.4 & 24.6 \\
\hline Histidine & $\mathrm{g} / \mathrm{kg}$ & 13.5 & 13.2 & 10.2 \\
\hline Phenylalanine & $\mathrm{g} / \mathrm{kg}$ & 23.9 & 24.1 & 20.5 \\
\hline Correlation & & Amino acids & $r^{2}$ & Significance \\
\hline \multirow{12}{*}{ Crude protein } & \multicolumn{2}{|r|}{ Methionine } & 0.9383 & 0.1124 \\
\hline & \multicolumn{2}{|r|}{ Cystine } & 0.5431 & 0.3173 \\
\hline & \multicolumn{2}{|r|}{ Methionine+Cystine } & 0.9676 & 0.0812 \\
\hline & \multicolumn{2}{|r|}{ Lysine } & 0.9862 & 0.0529 \\
\hline & \multicolumn{2}{|r|}{ Threonine } & 0.9999 & 0.0001 \\
\hline & \multicolumn{2}{|r|}{ Tryptophan } & 0.9802 & 0.0634 \\
\hline & \multicolumn{2}{|r|}{ Arginine } & 0.9968 & 0.0001 \\
\hline & \multicolumn{2}{|r|}{ Isoleucine } & 0.9996 & 0.0001 \\
\hline & \multicolumn{2}{|r|}{ Leucine } & 0.9985 & 0.0001 \\
\hline & \multicolumn{2}{|r|}{ Valine } & 0.9511 & 0.0999 \\
\hline & \multicolumn{2}{|r|}{ Histidine } & 0.9730 & 0.0741 \\
\hline & \multicolumn{2}{|r|}{ Phenylalanine } & 0.9949 & 0.0001 \\
\hline
\end{tabular}


results demonstrate that meal $C$ presented the lowest dry matter excretion per hour, i.e., the slowest passage rate, and therefore, it remained longer in the gut, followed by meal A, and whereas meal B presented the fastest passage rate.

The AME, AMEn, TME and TMEn values presented in Table 6 show the differences among the evaluated meals.

The apparent and true coefficients of metabolizability of dry matter and gross energy are in Table 7 . The differences determined are negligible when the standard deviations of the means are considered.

Table 5 - Gastrointestinal passage rate of the tested poultry offal meals.

\begin{tabular}{lll}
\hline \multirow{2}{*}{ Poultry offal meals } & Ether extract & Passage rate \\
\cline { 2 - 3 } & $\%$ & $\mathrm{~g} \mathrm{DM} / \mathrm{h}^{1}$ \\
\hline \hline $\mathrm{A}$ & 15.42 & $7.62 \pm 0.59 \mathrm{BC}$ \\
$\mathrm{B}$ & 11.47 & $8.17 \pm 0.96 \mathrm{~A}$ \\
$\mathrm{C}$ & 22.77 & $6.78 \pm 0.87 \mathrm{C}$ \\
Mean & & $7.52 \pm 0.36$ \\
F & & 3.622 \\
P & & 0.0588 \\
CV, \% & 10.92 \\
\hline \hline
\end{tabular}

\begin{tabular}{|c|c|c|c|}
\hline Parameter & & Correlation & Significance \\
\hline Passage rate & Ether extract & -0.9986 & 0.0076 \\
\hline
\end{tabular}

Means in the same column followed by the same capital letters are not different by the test of Student-Newman-Keuls

1 Grams of dry matter excreted per hour

The results of the $\mathrm{F}$ test revealed that the apparent metabolizability of dry matter was not different from the true metabolizability (Table 7).

The ratio between ashes and ether extract influenced the metabolizable energy values of the meals, and the following ratios between ashes and ether extract found were: $0.66 ; 0.82$ and 0.49 , for meals $A, B$ and $C$, and metabolizable energy values were $16,723,15,781$ and $17,439 \mathrm{MJ} / \mathrm{kg}$, respectively. These ratios imply that the high fat content in meals will not necessarily mean that their energy will be well utilized.

\section{DISCUSSION}

Dry matter and moisture contents may indicate overor under-heating of meals during processing. Bellaver \& Zanotto (2004) mentioned that the desirable moisture levels are between 40 and $100 \mathrm{~g} / \mathrm{kg}$, and therefore, the three tested poultry offal meals are within this optimal range, suggesting that processing was adequate, taking only moisture into consideration.

The predominance of determined body parts used when manufacturing poultry meals have a strong influence of their crude protein, ether extract, and ashes content. Analyzing 22 poultry offal meals, Dale et al. (1993) found mean values of 478, 296 and 66 $\mathrm{g} / \mathrm{kg}$ for those parameters respectively. The significant differences detected among the evaluated meals in ether extract and ashes contents may be attributed to the proportions of raw materials used during manufacturing, particularly in the proportions of head, back, and feet.

Literature information (Nascimento et al., 2002; Paula et al., 2002; Tucci et al., 2003; D’Agostini et al., 2004; Nunes et al., 2005; Nery, 2005; Brumano et al., 2006a; Nunes et al. , 2006; Melo, 2007; Ramalho, 2008) on the composition of poultry offal meals produced in Brazil show that $47 \%$ of the meals presented crude protein (CP) contents between 577 and $614 \mathrm{~g} / \mathrm{kg}$, and ashes between 118 and $162 \mathrm{~g} / \mathrm{kg}$, and that about $290 \mathrm{~g} / \mathrm{kg}$ of the samples contained between 101 and $161 \mathrm{~g} / \mathrm{kg}$ of ether extract (EE). However, the 53, 36 and $71 \% \mathrm{CP}$, ashes and $\mathrm{EE}$ contents obtained in the tested meals were not within that range, confirming the heterogeneity of processing methods, particularly relative to fat content.

The variation observed in EE content may be related to how digesters are fed, as well as to how meals are fried. Offal may be transported to the digester by gravity with the use of water, by augers or by belts. The two last methods directly feed the digester, maintaining the integrity of the raw materials, which are still raw. The water used to transport the offal by gravity is separated

Table 6 - Energy values de different poultry offal meal'1.

\begin{tabular}{|c|c|c|c|c|}
\hline \multirow{2}{*}{ Poultry offal meals } & AME & AMEn & TME & TMEn \\
\hline & $\mathrm{MJ} / \mathrm{kg}$ & $\mathrm{MJ} / \mathrm{kg}$ & $\mathrm{MJ} / \mathrm{kg}$ & $\mathrm{MJ} / \mathrm{kg}$ \\
\hline$A$ & $18.942 \pm 0.226^{2}$ & $16.723 \pm 0.185^{2}$ & $19.138 \pm 0.232^{2}$ & $16.810 \pm 0.188^{2}$ \\
\hline B & $17.987 \pm 0.307$ & $15.781 \pm 0.258$ & $18.134 \pm 0.174$ & $15.884 \pm 0.257$ \\
\hline C & $19.276 \pm 0.370$ & $17.441 \pm 0.329$ & $19.469 \pm 0.385$ & $17.525 \pm 0.336$ \\
\hline
\end{tabular}

1 Values expressed on as-is basis

2 Mean \pm standar error 
Table 7 - Apparent and true metabolizability of dry matter and gross energy ${ }^{1}$.

\begin{tabular}{|c|c|c|c|c|c|c|c|}
\hline \multirow{2}{*}{ Parameters } & \multicolumn{4}{|c|}{ Poultry offal meals } & \multirow[t]{2}{*}{ Mean $^{2}$} & \multirow[t]{2}{*}{$\mathbf{P}^{3}$} & \multirow[t]{2}{*}{ CV.4 \% } \\
\hline & Unit & A & B & C & & & \\
\hline \multicolumn{8}{|c|}{ Dry matter metabolizability } \\
\hline $\mathrm{DMMC}-\mathrm{A}$ & $\%$ & $69.89 \mathrm{~A}^{\mathrm{a}}$ & $69.36 \mathrm{~A}^{\mathrm{a}}$ & $69.61 \mathrm{~A}^{\mathrm{a}}$ & $69.62 \pm 1.57$ & NS & 5.07 \\
\hline DMMC - T & $\%$ & $71.33 \mathrm{~A}^{\mathrm{a}}$ & $71.08 \mathrm{~A}^{\mathrm{a}}$ & $71.04 \mathrm{~A}^{\mathrm{a}}$ & $71.17 \pm 1.60$ & NS & 5.05 \\
\hline $\mathrm{F}$ & & NS & NS & NS & & & \\
\hline CV & $\%$ & 4.43 & 5.85 & 4.78 & & & \\
\hline \multicolumn{8}{|c|}{ Gross energy metabolizability } \\
\hline GEMC - A & $\%$ & $76.8 A^{a}$ & $75.8 A^{a}$ & $75.3 \mathrm{~A}^{\mathrm{a}}$ & $75.98 \pm 1.98$ & NS & 3.52 \\
\hline GEMC - T & $\%$ & $77.2 \mathrm{~A}^{\mathrm{a}}$ & $76.3 A^{a}$ & $75.7 \mathrm{~A}^{\mathrm{a}}$ & $76.38 \pm 1.20$ & NS & 3.54 \\
\hline $\mathrm{F}$ & & NS & NS & NS & & & \\
\hline CV & $\%$ & 2.48 & 3.64 & 4.26 & & & \\
\hline
\end{tabular}

Means followed by the same small letters in the same row are not different by the test of Student-Newman-Keuls

Means in the same column followed by the same capital letters are not different by the $\mathrm{F}$ test.

Values expressed on as-is basis; ${ }^{2 M e a n} \pm$ standard error; ${ }^{3}$ Probability; ${ }^{4}$ Coefficient of variation

DMMC - dry matter metabolizability coefficient; GEMC - gross energy metabolizability coefficient; A - Apparent; T - True

using a sieve. Part of the water returns to the featherplucking area, and aids transporting the feathers. However, this water also transports part of the visceral fat, which binds to the feathers during transport (Maffi, 1993); therefore, the chemical components of the poultry offal meal are not fully utilized. According to Maffi (1993), this practice in rendering plants allows saving water in the system.

Another explanation of the high variability in the fat content of poultry offal meals may be located to where the raw material is cooked in the digester. In order to improve this process, some rendering plants add to the mass approximately $35.7 \mathrm{~g} / \mathrm{kg}$ of fat (Sabino \& Finzer, 2006), and consequently this fat is added to that present in the raw material, influencing poultry offal meal fat content.

The average levels of calcium and phosphorus of the tested poultry offal meals were different from those reported in some research studies (Nascimento et al., 2002; Soares et al., 2005; Brumano et al., 2006a; Nunes et al., 2006), which presentd mean values of 37.1 and 27.3, respectively, and a calcium:phosphorus ratio of 1.36:1. Calcium and phosphorus levels obtained in the present study were also different from those in the ten poultry offal meals analyzed by Najafabadi et al. (2007), but the calcium:phosphorus ratio of 1.8:1 obtained here was consistent with that study. The variation in the proportion of parts that compose the residue sent to the rendering plant may justify these results, when considering carcass processing and trading. Some companies debone breasts and legs, and therefore breast cartilage and leg bones are included in the residue commonly sent to the rendering plant (Roque, 1996), contributing to the variation in the levels of calcium and phosphorus in poultry offal meals. The technological level of the processing plants may also influence those levels relative to the recovery of meat adhered to the parts, particularly in the breast and neck (Roque, 1996), that is, a better recovery of meat increases the proportion of bones in the meal, and consequently, increases its calcium and phosphorus content.

There are few studies in literature relative to sodium, chlorine and potassium levels in poultry offal meals. In a sample of poultry offal meal with $246.3 \mathrm{~g} / \mathrm{kg}$ of ashes, analyzed by Nunes et al. (2005), levels of $6.2 \mathrm{~g} /$ $\mathrm{kg}$ of sodium and $4.8 \mathrm{~g} / \mathrm{kg}$ potassium were determined. The 13 poultry offal meals evaluated by Robbins \& Firman (2006), with ashes contents between 10 and $28 \mathrm{~g} / \mathrm{kg}$, sodium and potassium values of 5.6 and 6.8 $\mathrm{g} / \mathrm{kg}$, respectively, were found. The authors found that the levels of those minerals were negatively correlated with ash content, with the highest Na value $(8.8 \mathrm{~g} / \mathrm{kg})$ obtained from a meal with $100 \mathrm{~g}$ ashes $/ \mathrm{kg}$, and the lowest $\mathrm{K}$ concentration in the meal containing $280 \mathrm{~g}$ ashes $/ \mathrm{kg}$. Najafabadi et al. (2007) analyzed 10 poultry offal meals and obtained average values of ashes $(93.4 \mathrm{~g} / \mathrm{kg})$, sodium $(5.2 \mathrm{~g} / \mathrm{kg})$, potassium $(3.1 \mathrm{~g} / \mathrm{kg})$ and chlorine $(7.4 \mathrm{~g} / \mathrm{kg})$ which varied $22.2,11.5,16.1$, and $9.5 \%$, respectively among meals. To date, literature does not provide clear explanations for these variations. 
The significant negative correlation between these three minerals and ashes content found in the present study may be used as a tool for nutritionists to correct the variations in sodium, chlorine and potassium contents, using the ratios of $45.6,57.4$ and $74.4 \mathrm{~g} / \mathrm{kg}$ ashes, respectively.

In summary, differences in the chemical composition of poultry offal meals are a result of the criteria and methods applied in the processing plants as well as for processing this by-product in the rendering plants. These differences are very common, because, according to Lopez (2005), there is no legal standardization of the chemical composition of poultry offal meal in Brazil, and the composition is usually determined by the feed manufacturing companies.

Information in raw material density is important and should be considered when designing feeding strategies, particularly when least cost formulations are used. The density of alternative feedstuffs should be similar to those of corn $(724-757 \mathrm{~g} / \mathrm{L})$ and soybean meal (639 - $675 \mathrm{~g} / \mathrm{L})$, according to Rodrigues et al. (2001) and Rodrigues et al. (2002). It is well known that, among factors regulating feed intake, physical limitations, i.e., the distension of the gut muscles, are imposed when high levels of light feedstuffs are included in the feed, because the stomach is quickly filled (Gonzales et al., 2002). Poultry offal meals, however, present higher energy density than soybean meal, as shown by the density and metabolizable energy values obtained bt Rodrigues et al. (2002). Comparatively, at the same energy supply, one cubic centimeter of poultry offal meal corresponds to $1.6 \mathrm{~cm}^{3}$ of soybean meal, which may attenuate the gut-filling effects caused by the low density of poultry offal meals.

Particle geometric mean diameter is correlated to the development of the gizzard muscles (Ribeiro et al., 2002) and to digesta passage rate in the digestive tract (Nir et al., 1994). The average geometric mean diameter obtained in the present study was close to the value of $619 \mu \mathrm{m}$ recommended by Ribeiro et al. (2002) to improve dietary energy metabolizability.

The determination of the amino acid composition of feedstuffs is currently required in feed formulation to precisely supply the amino acid requirements of animals. This is particularly important for poultry offal meal, which may present widely different protein levels. In addition of the absolute values, the ratio among amino acids must also be considered. In general, amino acid absolute values varied according to the crude protein content of the meals, except for sulfur amino acids, particularly cystine. The low correlation coefficient between crude protein and this amino acid may be attributed to the different cooking times and temperatures used for processing methods of poultry offal meals. According to Moritz \& Latshaw (2001) cystine can be considered heat sensitive. Therefore, it may be inferred that poultry offal meals $B$ and $C$ may have been submitted to conditions that compromised cystine stability. Leucine, lysine and valine presented the widest variation among amino acids in the tested poultry offal meals, which was also observed by Nascimento (2000) and Brumano et al. (2006b). The ratio among valine, leucine and isoleucine has been discussed in literature, as they present specificity for the membrane transport system and use the same enzymes for this end (Peganova \& Eder, 2003). However, in practical diets, these amino acids are not included to correct possible unbalances, reinforcing the need of having detailed information of the ratio among these amino acids in the feedstuffs.

According to Swenson \& Reece (1996), longer permanence times of feed in the gut allow better enzymatic action on the macromolecules and, consequently, higher release of monomers on the surface of the brush border of the enterocytes, and this is considered one of the extra-caloric effects of dietary fats. This phenomenon is allowed by action of fats, which stimulate the secretion of cholecystokinin (CCK) and motilin, according to Martínez et al. (1993;1995) and Rodríhuez-Sinovas et al. (1997). However, this effect is not constant, as there are reports that high fat content, together with high ashes content, may result in high fatty acid and calcium levels in the digesta, causing successive saponification reactions with the formation of insoluble soaps during digestion, with consequent reduction of absorption, particularly of unsaturated fatty acids (Lessire et al., 1985; Pesti et al., 1986; Martosiswoyo \& Jensen, 1988). Therefore, ashes to ether extract ratios ( $A / E E$ ) higher or equal to 1.0 may reduce the energy content of poultry offal meals, according to Nunes et al. (2006), who evaluated poultry offal meals with 1.17 and $1.02 \mathrm{~A} / \mathrm{EE}$ ratios and observed final energy values of 11.512 and 12.847 $\mathrm{MJ} / \mathrm{kg}$, respectively.

\section{Metabolism assay}

Considering the influence of ashes to ether extract ratios on the metabolizable energy values of poultry offal meals, $0.66,0.82$ and 0.49 ratios and metabolizable energy values of $16.723,15.781$ and $17.439 \mathrm{MJ} / \mathrm{kg}$ for meals meal $\mathrm{A}, \mathrm{B}$ and $\mathrm{C}$, respectively, 
were obtained in the present study. These ratios indicate that the energy utilization of meals with high fat content will not necessarily be adequate.

The energy values of three tested poultry offal meals were higher than those determined by Brumano et al. (2006), who obtained 59\% gross energy metabolizability, corresponding to $12.516 \mathrm{MJ} / \mathrm{kg}$ apparent metabolizable energy corrected for nitrogen (AMEn) for a poultry offal meal with high fat content $(200 \mathrm{~g} / \mathrm{kg} \mathrm{EE})$. On the other hand, the calcium level of that meal was, in average, $60 \%$ higher than the poultry offal meals tested in the present experiment.

Other factors may also influence energy utilization in broilers, including primarily feedstuff quality and secondly the methodology applied for energy determination, replacement levels, and Bird age at the time of collection. These are only the factors affecting the method of total excreta collection.

As to feedstuff quality, Racanicci et al. (2004) stressed that the fatty acid profile of the fat in poultry offal meals influences the development of lipid oxidation. According to those authors, for each gram of oxidized fat in the feedstuff, $17 \%$ fat utilization is lost compared with a gram of non-oxidized fat.

The effects of the method of determination on metabolizable energy values were studied by Pesti et al. (1986). The methods of Matterson et al. (1965), Hill \& Anderson (1958) and Sibbald (1976) were tested by Pesti et al. (1986), when evaluating poultry offal meals, and the values of $12,516,11,449$ and $16.409 \mathrm{MJ} / \mathrm{kg}$ were obtained for the respective methods, thereby proving those effects.

The determination of apparent metabolizable energy corrected for nitrogen in broilers proposed by Rostagno et al. (2005) uses the method of total excreta collection. The value presented by those authors for high-fat poultry offal meal was lower than those obtained for the tested poultry offal meals $A, B$, and $C$ in the present experiment of $0.368,1.310$ and $2.026 \mathrm{MJ} / \mathrm{kg}$, respectively. These results substantiate the hypothesis of Nunes et al. (2001), who stressed the importance of developing studies to improve the recommendation tables, making them more complete and precise.

The level of feedstuff replacement used in that method for the determination of metabolizable energy in the tested poultry offal meals was questioned by the authors. The energy values were obtained using $25 \%$ poultry offal meal; for this level, according to the equations of Paula et al. (2002) and Nascimento et al. (2005), AMEn values were 15,019 and 12,688 MJ/kg, respectively. Despite the different calculated values, these differences may be justified by the chemical composition of the feedstuffs, and there is consensus among authors that increasing inclusion levels reduce the metabolizable energy values of poultry offal meals.

The effect of bird age during the period of collection is also important. The positive visceral allometric growth in broiler chicks results in the development of the digestive tract and in an increase in enzyme secretion and absorption area (Sklan, 2001). These physiological event affect feed passage rate and, consequently, metabolizable energy values. Nascimento et al. (2005) determined poultry offal meal AMEn at two ages (16 - 23 and 30 - 38 days of age) and found a $0.435 \mathrm{MJ} /$ $\mathrm{kg}$ increase in metabolizability. Similarly, Brumano et al. (2006a), using broilers with average ages of 25 and 45 days, found AMEn values of 12,516 and 13,278 MJ/ $\mathrm{kg}$ for poultry offal meal, confirming the additive effect of age on energy utilization. However, these values are lower than those obtained in the present study, stressing the importance of standardizing the chemical composition of poultry offal meals, preserving their quality during processing and storage, and showing that low ratios between ashes and fat should be avoided.

According to Oliveira (1996), the heat treatment used during poultry offal meal processing may eliminate Salmonella present in the viscera, but Nunes et al. (2006) stress that the temperature applied may break the bonds among amino acids that maintain the tridimensional structure of protein, as well as promoting the formation of complexes among nutrients, rendering them indigestible and, as their absorption is reduced, the gross energy metabolizability of the feedstuff may be affected. The magnitude of these effects varies according to the processing methodology employed by the rendering companies (Albino et al., 1982; Albino et al., 1986). This means that fecal metabolic and endogenous urinary dry matter losses had little influence on the amounts excreted by the birds. This also applies to gross energy metabolizability, as GEMC-T considers fecal metabolic and endogenous urinary dry matter, fecal metabolic and endogenous urinary nitrogen, and fecal metabolic and endogenous urinary energy. In terms of methodology, feed intake has an important influence on endogenous and metabolic losses in metabolism assays (Silva et al., 2006). Coelho et al. (1983) and Lima et al. (1989) reported that, at normal intake levels, endogenous and metabolic losses are small relative to the excretion of energy derived from feed and have little influence on metabolizable energy values. 


\section{CONCLUSIONS}

The tested poultry offal meals presented variable physical-chemical composition, leading to changes in passage rate and in energy utilization, particularly due to their fat and mineral contents.

\section{ACKNOWLEDGEMENTS}

The authors thank the companies Mauricéa Alimentos do Nordeste Ltda, Notaro Alimentos and Agropecuária Serrote Redondo for donating the poultry offal meals, as well as the Soil Fertility and Chemistry Laboratory of Universidade Federal Rural de Pernambuco (UFRPE), Animal Nutrition Laboratory of Universidade Federal Rural do Semi-árido (UFERSA) and the company empresa DEGUSSA, which kindly performed the required analysis.

\section{REFERENCES}

Agricultural Research Council. The nutritional requirement of ruminant livestock. London: CAB International; 1980.

Albino LFT, Ferreira AS, Fialho ET, César JS. Determinação dos valores de energia metabolizável e matéria seca aparentemente metabolizável de alguns alimentos. Revista da Sociedade Brasileira de Zootecnia 1982; 11(2):207-221

Albino LFT, Fialho ET, Blume E. Energia metabolizável e composição química de alguns alimentos para frangos de corte. Revista da Sociedade Brasileira de Zootecnia 1986; 15(3):184-192.

Bellaver C, Zanotto DL. Parâmetros de qualidade em gorduras e subprodutos proteicos de origem animal. Anais da Conferência Apinco de Ciência e Tecnologia Avícolas; 2004; Santos, São Paulo. Brasil. v.1, p.79-1102.

Brumano G, Gomes PC, Albino LFT, Hostagno HS, Geeneroso RAR, Schmidt M .Composição química e valores de energia metabolizável de alimentos proteicos determinados com frangos de corte em diferentes idades. Revista Brasileira de Zootecnia 2006a; 35(6):2297-2302.

Brumano G, Gomes PC, Rostagno HS, Albino LFT, Schmidt M, Generoso RAR. Aminoácidos digestíveis verdadeiros de alimentos protéicos determinados em galos cecectomizados. Revista Brasileira de Zootecnia 2006b; 35(6):2290-2296.

Coelho MGR, Rostagno HS, Fonseca JB, Silva DJ. Composição química e valores energéticos de alguns alimentos, determinados com pintos e galos. Anais do 8 Congresso Latino-Americano de Avicultura;1983; Camboriú, Santa Catarina. Brasil. Camboriú: ACA/UBA; 1983. p.79-95.

Compêndio Brasileiro de Brasileiro de Alimentação Animal. São Paulo: Sindirações/Anfar, Campinas: CBNA/SDR/MA; 2004.

D’agostini P, Gomes PC, Albino LFT, Rostagno HS, Sá LM. Valores de composição química e energética de alguns alimentos para aves. Revista Brasileira de Zootecnia 2004; 33(1):128-134.

Dale N, Fancher B, Zumbado M, Villacres A. Metabolizable energy content of poultry offal meal. Journal Applied Poultry Research 1993; 2(1): 4042.

Gonzáles E. Ingestão de alimentos: mecanismos regulatórios. In: Macari M, Furlan R L, Gonzáles E, editor. Fisiologia aviária aplicada a frangos de corte. Jaboticabal: FUNEP/UNESP; 2002. p. 187-199.

Hill FW, Anderson DL. Comparation of metabolizable energy and productive energy determination with growing chicks. The Journal of Nutrition 1958; 64(4):587-608

Lessire M, Lequercq B, Conan L, Halliouis JA Methodological study of the relationship between the metabolizable energy values of two meat meals and their level of inclusion in the diet. Poultry Science 1985; 64(9): 1721-1728.
Lima IL, Silva DJ, Rostagno HS, Tafuri ML. Composição química e valores energéticos de alguns alimentos determinados com pintos e galos, utilizando duas metodologias. Revista da Sociedade Brasileira de Zootecnia 1989; 18(6):546-556

Lopes MH. Resposta técnica. Serviço brasileiro de respostas técnicas; 2005. p. 1-3 [citado 2007 maio]. Disponível em: http: /www.sbrt.ibict.br

Maffi GL. Graxarias e subprodutos. Anais da Conferência Apinco de Ciências e Tecnologia Avícolas; 1993; Santos, São Paulo. Brasil. Campinas: Fundação APINCO de Ciências e Tecnologia Avícolas; 1993. p.191-201.

Martinez V, Jiménez M, Goñlons E, Vergara P. Mechanism of action of CCK in avian gastroduodenal motility: evidence for nitric oxide involvement. American Journal Physiology Gastrointestinal and Liver Physiology 1993; 28(5): G842-G850.

Martinez V, Jimenez M, Goñalons E, Vergara P. Modulation of the migration myoeletric complexs by and gastrin the gastrointestinal tract of chickens. Poultry Science 1995; 74(3):563-576.

Martosiswoyo AW, Jensen LS. Available energy in meat and bone meal as measured by different methods. Poultry Science 1988; 67(2):280-293.

Matterson LD, Potter LM, Stutz MW. The metabolizable energy of feed ingredients for chickens. Agricultural Experimental Station Research Report 1965; 7:3-11.

Melo HHC. Determinação dos valores de energia metabolizável de alimentos com aves de diferentes idades [dissertação]. Viçosa (MG) Universidade Federal de Viçosa; 2007

Moritz JS, Latshaw JD. Indicators of nutritional value of hydrolyzed feather meal. Poultry Science 2001; 80(1):79-86

Najafabadi HJ, Moghddam HN, Pourreza J. Determination of chemical composition, mineral contents, and protein quality of poultry byproduct meal. International Journal of Poultry Science 2007; 6(12):875882

Nascimento $\mathrm{AH}$. Determinação do valor nutritivo da farinha de vísceras e da farinha de penas para aves, utilizando diferentes metodologias [tese]. Viçosa(MG): Universidade Federal de Viçosa; 2000.

Nascimento AH, Gomes PC, Albino LFT, rostagno, H.S.; TORRES, R.A. Composição química e valores de energia metabolizável das farinhas de penas e vísceras determinados por diferentes metodologias para aves. Revista Brasileira de Zootecnia 2002;31(3):1409-1417.

Nascimento AH, Gomes PC, Rostagno HS, Albino LFT, Donzele JL. Valores de energia metabolizável de farinhas de penas e de vísceras determinados com diferentes níveis de inclusão e duas idades das aves. Revista Brasileira de Zootecnia 2005;34(3):877-881.

Nery LR. Valores de energia metabolizável e de aminoácido digestível de alguns alimentos para aves [dissertaçãp]. Viçosa(MG): Universidade Federal de Viçosa; 2005.

Nir I, Shefet Y, Aroni G. Effect of particle size on performance. I. Corn. Poultry Science 1994;73(1):45-49.

Nunes RV, Pozza PC, Nunes CGV, Campestrini E, Kühl R., Rocha LD, Costa FGP.Valores energéticos de subprodutos de origem animal para aves. Revista Brasileira de Zootecnia 2005; 34(4):1217-1224.

Nunes RV, Rostagno HS, Albino LFT, Gomes PC, Toledo RS. Composição bromatológica, energia metabolizável e equações de predição da energia do grão e de subprodutos do trigo para pintos de corte. Revista Brasileira de Zootecnia 2001; 30(3):785-793

Nunes RV, Rostagno HS, Gomes PC, Nunes CGV, Albino LFT, Pozza PC, Dionizio MA, Araújo MSA.Valores energéticos de diferentes alimentos de origem animal para aves. Revista Brasileira de Zootecnia 2006; 35(4):1752-1757

Oliveira G. Avaliação dos pontos críticos de contaminação por Salmonella sp no processo de fabricação da farinha de vísceras destinadas à fabricação de rações para aves [dissertação]. Porto Alegre (RS): Universidade Federal do Rio Grande do Sul; 1996.

Paula A, Brum PAR, Avila VS, Maier JC. Valores de energia metabolizável da farinha de carne e ossos e farinha de vísceras determinados com diferentes níveis de substituição para frangos de corte. Revista Brasileira de Agrociência 2002; 8(1): 51-55

Peganova S, Eder K. Interactions of various supplies of isoleucine, valine leucine and tryptophan on the performance of laying hens. Poultry Science 2003; 82(1): p.100-105.

Pesti GM, Faust LO, Fuller HL, Dale NM, Benoff FH. Nutritive value of poultry by-product meal. 1. Metabolizable energy values as influenced 
by method of determination and level of substitution. Poultry Science 1986; 65(12): 2258-2267.

Racanicci AMC, Menten JFM, Regitano-D'Arce MAB, Gaiotto JB, Longo FA, Pedroso AA, Sorbara JOB. Oxidação lipídica do óleo de vísceras de aves para redução de seu conteúdo de energia metabolizável para frangos de corte na fase de crescimento. Revista Brasileira de Zootecnia 2004; 33(4): 919-923.

Ramalho VRRAR. Avaliação nutricional de subprodutos de abatedouros avícolas para frangos de corte [tese]. Recife: Universidade Federal Rural de Pernambuco; 2008. 133p.

Ribeiro AML, Magro N, Penz Jr AM. Granulometria do milho em rações de crescimento de frangos de corte e seu efeito no desempenho e metabolismo. Revista Brasileira de Ciência Avícola 2002; 4(4): 1-7.

Robbins DH, Firman JD. Evaluation of the metabolizable energy of poultry by-product meal for chickens and turkeys by various methods. International Journal of Poultry Science 2006; 5(8): 753-758.

Rodrigues PB, Rostagno HS, Albino LFT, Gomes PC, Barboza WA, Santana RT. Valores energéticos do milheto, do milho e subprodutos do milho, determinados com frangos de corte e galos adultos. Revista Brasileira de Zootecnia 2001; 30(6): 1767-1778.

Rodrigues PB, Rostagno HS, Albino LFT, Gomes PC, Nunes RV, Santana TR. Valores energéticos da soja e subprodutos da soja, determinados com frangos de corte e galos adultos. Revista Brasileira de Zootecnia 2002; 31(4): 1771-1782.

Rodríguez-Sinovas $A$, Jiménez $M$, De Clercq $P$, Peeters $T L$, Vergara $P$. Rhythmic oscillating complexes in gastrointestinal tract of chickens: a role for motilin. American Journal Physiology. Gastrointestinal and Liver Physiology 1997; 35(4): G916-G922.

Roque VF. Aproveitamento de resíduos de carne de frango: uma análise exploratória [dissertação]. Florianópolis: Universidade Federal de Santa Catarina; 1996. 84p

Rostagno H S, Albino LFT, Donzele JLD, Gomes PC, Ferreira AS, Oliveira RFM, Lopes DC. Tabelas brasileiras para aves e suínos: composição de alimentos e exigências nutricionais. Viçosa: Departamento de Zootecnia; 2000. v.1, 124 p.

Rostagno HS, Albino LFT, Donzele JL, Gomes PC, Oliveira RF, Lopes D C, Ferreira AS, Barreto SLT. Tabelas brasileiras para aves e suínos composição de alimentos e exigências nutricionais. 2. ed. Viçosa: Departamento de Zootecnia; 2005. v.2, 186 p.

Sabino HFN, Finzer JRD. Subprodutos no processamento de aves. Anais da $5^{a}$ Jornada Científica, Faculdades Associadas de Uberaba; 2006; Uberaba, Minas Gerais. Brasil. Uberaba: Faculdades Associadas de Uberaba; 2006.

Sibbald IR. A biossay for true metabolizable energy in feedingstuffs. Poultry Science 1976; 55(1): 303-308.

Silva DJ, Queiroz AC. Análise de alimentos: métodos químicos e biológicos. 3.ed. Viçosa: Editora UFV; 2002. 235p.

Silva EP, Rabello CBV, Lira RC, Farias Filho RV, Albuquerque CS, Silva DAT. Estimativa das perdas endógenas e metabólicas em frangos de corte. Revista Brasileira de Ciências Agrárias 2006; 1: 115-121.

Sklan D. Development of the digestive tract of poultry. World's Poultry Science Journal 2001;57(4): 415-428.

Soares KR, Bertechini AG, Fassani ÉJ. Valores de energia metabolizável de alimentos para pintos de corte na fase pré-inicial. Ciência e Agrotecnologia 2005; 29(1): 238-244.

Swenson MJ, Recce WO. Dukes: fisiologia dos animais domésticos. $11^{\text {th }}$ ed. Rio de Janeiro: Guanabara Koogan; 1996.

Tucci FM, Laurentiz AC, Santos EA, Rabello CBV, Longo FA, Sakomura NK Determinação da composição química e dos valores energéticos de alguns alimentos para aves. Acta Scientiarum. Animal Sciences 2003; 25(1): 85-89.

UFV - Universidade Federal de Viçosa. SAEG -Sistema de análises estatísticas e genéticas. Versão 9.1. Viçosa; 2006.

Zanotto DL, Bellaver C. Métodos de determinação da granulometria de ingredientes para uso em rações de suínos e aves [comunicado técnico, 215]. Concórdia: Embrapa-Cnpsa; 1996. p.1-5. 


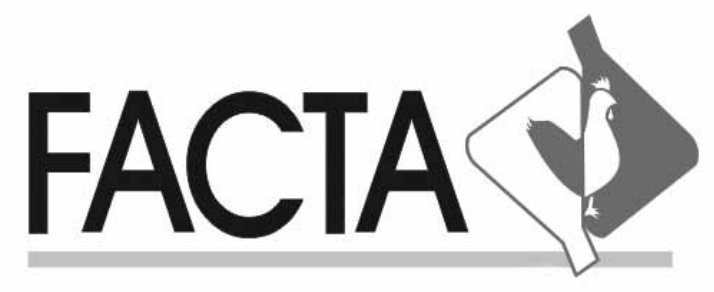

\section{Prêmio Lamas 2013 Prepare seu trabalho científico.}

A chamada para o Prêmio Lamas 2013 deverá ser divulgada em breve.

Para mais informações: facta@facta.org.br ou Fone 5519 3243-6555 